\title{
A Comparative Study on Sustainable Procurement Practices in Sisal Processing Firms in Nakuru County
}

\author{
Muma Benard, Eunice Waruguru, Caroline Mundia, Sophie Kiruri \\ Department of Accounting, Finance and Management Science, Egerton University, Nakuru, Kenya
}

\section{Email address:}

mumabenard@gmail.com (M. Benard), yunnywa@yahoo.com (E. Waruguru), carolinemundia@yahoo.com (C. Mundia), sophiekiruri@yahoo.com (S. Kiruri)

\section{To cite this article:}

Muma Benard, Eunice Waruguru, Caroline Mundia, Sophie Kiruri. A Comparative Study on Sustainable Procurement Practices in Sisal Processing Firms in Nakuru County. International Journal of Economics, Finance and Management Sciences. Vol. 3, No. 5, 2015 , pp. 453-459. doi: 10.11648/j.ijefm.20150305.16

\begin{abstract}
Sustainability in business operations continues to attract much attention in the business environment and so is among researchers. This is due to the benefits organizations enjoy when they achieve internal sustainability. While most organizations adopt sustainable business practices for various reasons; to improve performance and to be responsive to stakeholders' demands, some organizations just adopt these strategies s a formality. In developing countries for instance, most organizations do not take a strategic approach to sustainability in internal business organizations. It is clear that studies need to be conducted on sustainability so that recommendations can be made to management of processing and manufacturing firms to enhance sustainability. This study sought to establish the level to which sisal processing firms in Nakuru County adopt sustainable procurement activities and further compare the level of adoption between the two major sisal processing firms in Nakuru County; Athinai Sisal Estate Lomolo (1962) Ltd. The study adopted a comparative study design and was guided by four objectives; To compare the level Supply Chain Efficiency between Athinai Sisal Estate and Lomolo (1962) Ltd., To compare Supply Chain Risk Management practices between Athinai Sisal Estate Lomolo (1962) Ltd., To compare attention to Stakeholder's Expectation and Awareness between Athinai Sisal Estate Lomolo (1962) Ltd. And To compare Supply Chain Organizational Policy Commitment between Athinai Sisal Estate Lomolo (1962) Ltd. The study findings revealed that the two firms adopt similar sustainable procurement activities. However, Athinai Sisal Estate was found to adopt these practices at much higher level. The study recommended that the processing and manufacturing organizations build sustainability in the internal business operations and take a strategic approach to sustainability. Sustainability in operations should not be left functional areas. It should be management led and should be a cross the organization. The researchers suggested that further studies should be done on other sustainable business practices such as reverse logistics, just in time and green supply chain management as well as establish the role of these practices in operational and other aspects of organizational performance.
\end{abstract}

Keywords: Sustainable Procurement, Sisal Processing Firms, Nakuru County

\section{Introduction}

\subsection{Background of the Study}

Sustainable procurement is a development of the traditional procurement. It is defined as a purchasing practice that takes into account the economic, social and environmental impact of the organization's procurement activities. Sustainable procurement enables organizations to obtain goods, services, works and other requirements without compromising on environmental conservation, social interests of stakeholders and economic needs of the organization and the nation (Principles and Practice of Public Procurement, 2012).
Sustainable procurement is about socially and ethically responsible purchasing, minimizing environmental degradation, achieving economic purchasing and maintaining good business practice in purchasing (Chartered Institute of Purchasing \& Supply, 2011). Similarly, Department of sustainability, Environment, Water, Population and Communities, Australian Government (2013) considers sustainable procurement as a purchasing system that ensures environmental concerns and social interests are taken into consideration and purchasing is done efficiently, effectively, economically and ethically. Sustainable procurement therefore considers three factors; environmental impacts, social impacts and economic impacts. 
Sustainable procurement has attracted interest from research in the recent past. From then, scholars have studied sustainable procurement. These studies have looked at sustainable procurement practices, elements of sustainable procurement as well as related such practices with other variables such as; environmental conservation and the various aspects of organizational performance. Supply Chain Management is made sustainable by being economically logical, environmentally friendly and socially meaningful (Sarkis, 2010). This is achieved through reuse of materials, remanufacture and environmentally friendly disposal of wastes.

\subsection{Objectives of the Study}

The general objective of the study is to investigate the relationship between Sustainable Procurement and Environmental Performance.

The study will be guided by the following specific objectives:

1. To compare the level Supply Chain Efficiency between Athinai Sisal Estate and Lomolo (1962) Ltd.

2. To compare Supply Chain Risk Management practices between Athinai Sisal Estate Lomolo (1962) Ltd.

3. To compare attention to Stakeholder's Expectation and Awareness between Athinai Sisal Estate Lomolo (1962) Ltd.

4. To compare Supply Chain Organizational Policy Commitment between Athinai Sisal Estate Lomolo (1962) Ltd.

\subsection{Hypotheses of the Study}

$\mathrm{Ho}_{1}$ : There is no significant difference between Supply Chain efficiency between Athinai Sisal Estate Lomolo (1962) Ltd.

$\mathrm{Ho}_{2}$ : There is no significant difference between the Supply Chain Risk Management practices between Athinai Sisal Estate Lomolo (1962) Ltd.

$\mathrm{Ho}_{3}$ : There is no significant difference between attention to Stakeholder's Expectation and Awareness between Athinai Sisal Estate Lomolo (1962) Ltd.

$\mathrm{Ho}_{4}$ : There is no significant difference between Supply Chain Organizational Policy Commitment between Athinai Sisal Estate Lomolo (1962) Ltd.

\subsection{Significance of the Study}

This study aimed to build literature that would stimulate further research on sustainable procurement. The findings of the study contributes contribute to adoption of sustainable procurement processing and manufacturing firms. The recommendations of this study can be useful to procurement organizations and procurement managers in understanding the adoption of sustainable procurement practices and the effects such practices have on operational performance of organizations adopting them

\subsection{Scope of the Study}

This study sought to establish the sustainable procurement practices in the sisal firms in Nakuru County. The two major firms in the county were used in the study. All employees in Procurement, Production, Marketing and Accounts and finance departments took part in the study. The study considered three indicators of sustainable procurement; Supply Chain Efficiency, Supply Chain Risk Management, Stakeholder's Expectation and Awareness and Supply Chain Organizational Policy Commitment

\section{Literature Review}

\subsection{Economic Organization Theory}

Economic organization theory looks at an organization as an entity within and through which individuals interact to achieve individual and collective goals. The main aim of existence of organizations according to this theory is to achieve economic gains. The economic performance of an organization is measured in terms of productivity, profitability and sustainability of its operations (Muma et al., 2014).

The theory of economic organization is grounded on building blocks. The first building block is coordination and motivation. Effective coordination is critical in an organization in deciding on what tasks to be performed, when they are to be performed, by whom they should be performed and in what priority. On the other hand, motivation is important in inspiring the employees to individually and collectively work towards achievement of set goals. The second building block is transactions and contracts. Through transactions, individuals and organizations plan and implement organizational operations. Contracts however provides a means through which agreements between the partners is coordinated. The contracts need not to be written, however, they should be clear be made on continuous basis as the business environment keeps changing. The third building block is bounded rationality. According to Simon (1951), cited by Fudenberg (1990), individuals are limited in their scope to act rationally. This is because of the limitations relating to accessible information and the conception ability of the individuals. The forth building block of the economic theory is the principal-agent framework. In many business activities, the principal agent relationship is adopted. There is need for free flow of information and motivation to ensure the agent knows the principal's requirements and is committed towards achieving them. The last building block is governance structure outlining the rules and regulations and procedures relating to transactions. There must be integration between procurement and other factional areas of the organization. The organization must also have structures that facilitate coordination and cooperation between functional areas (Fundenberg et al., 1990).

Sustainable procurement is one of the strategies that most organizations are currently adopting to achieve economic objectives. This theory brings an understanding on how the organization can align its structure and resources to implement sustainable procurement initiatives. It sets out the need to have coordination between functional areas of the organization, communication and building of organizational structures that 
facilitates partnership, key ingredients in implementing sustainable procurement.

\subsection{Krajlic's Model of Purchasing Portfolio}

According to Krajlic's model, different kind of sourcing operations require different sourcing relationships. Therefore, organizations sourcing variety of requirements must be keen on what kind of relationship to establish. The theory acknowledges the fact that resources are limited. Because of this, procurement activities must be done in the most economic as sustainable manner. Krajlic's model proposes that if an organization is able to achieve sustainable procurement, then the organization will automatically achieve improved procurement performance which in turn translates into improved organizational performance (Chkanikova, 2012). The model identifies four categories of sourcing portfolio as shown in figure 2.1.

\begin{tabular}{c|l|l|}
\cline { 2 - 3 } High & Leveraged Items & Strategic Items \\
\cline { 2 - 3 } Profit Impact & $\begin{array}{l}\text { Non-Critical } \\
\text { Items }\end{array}$ & Bottleneck \\
\hline \multicolumn{2}{|c}{ Supply Risk High }
\end{tabular}

Source: Chkanikova (2012)

Figure 2.1. Kraljic's model of purchasing portfolio.

\subsection{Supply Chain Efficiency}

Supply chain management:-is composed of internal logistics management that support flow of goods and services and associated information well as upstream and downstream linkages with suppliers and customers (Camerinelli, 2009). Chege (2012) and Muma et al. (2014) reports that supply chain management involves organizing and controlling supplier's processes, technology and capability to improve an organizations competitive advantage. It is also based on interaction of manufacturing, logistics, and material, distribution and transportation functions within an organization. Supply chain efficiency on the other hand describes how the process of Supply Chain Management is made sustainable by being economically logical, environmentally friendly and socially meaningful. Efficiency can be analyzed in four areas of supply Chain Management as stated in research by Chege (2012).This areas include: design, operations, inbound logistics and reverse and outbound logistics. These areas are explained as follows:

Design which describes planning activities and projects to be undertaken including providing design specifications to suppliers that includes requirement for purchased item, cooperation with suppliers in setting sustainable objectives, cooperation with suppliers for sustainable designs and cooperation with suppliers for sustainable packaging. This requires an organization to invest resources in cooperation activities that address sustainable issues and more specifically environmental issues in the supply chain. Zhu et al. (2007) explains that cooperation with suppliers and other members of supply chain helps to reduce environmental impacts of their activities. Eco-friendly designs need manufacturers to design products that minimize consumption of materials and energy, facilitate re-use, and recycle and recovery of component materials and parts and reduce use of hazardous products within manufacturing process.

Reverse and outbound logistics that proposes that efficient reverse logistics may be described as role of logistics in product returns, source reduction, recycling of wastes, material substitution, reuse of materials, waste disposal, refurbishing, and repairs and remanufacturing. The main aim is to reduce all forms of wastes (Sarkis, 2010).This will affect the environmental performance of the organization. Outbound logistics includes process that enables movement of products from the organization to the customers. Efficient Out-bound logistics includes a transportation system that minimizes usage of fuel, minimal damage to road network etc. (Kam et al., 2003)

Purchasing and inbound logistics:-Purchasing as a function is a procurement activity that begins from the time a need is felt to the time materials and goods are received and accepted by an organization (Saleemi, 1997). Purchasing forms the biggest part of inbound logistics. Inbound logistics this includes all activities that bridge the gap between the suppliers and the organization by availing products and raw materials to the organization. Efficient inbound logistics has a number of benefits including reduction, integrating suppliers to the organization so as to form participative decision making process that will ensure sustainability and more specifically environmental innovation (Bowen et al., 2001).

\subsection{Stakeholder Expectation and Awareness}

Stakeholders holders is a term that refers to people or organizations that are affected by activities of an organization and that affects the decisions and achievement of an organization goals (Wheeler et al., 2002). Increased Stakeholder's Expectation and Awareness is all about exerting pressure on organizations to consider economic, environmental and social aspects of business. Stakeholder is any group or individuals who can affect or be affected by the achievement of an organizations objective (Mosqaad, 2009). Stakeholder theory has modified the traditional view of organization that focuses on owner of the organization and their economic interest. The stakeholder theory holds that organizations like companies generate externalities that affect many parties which may be internal or external to the firm.

Externalities make stakeholders to increase pressure of firms to reduce negative impacts and improve positive ones. (Sarkis, 2007) The pressure of the internal and external stakeholders may influence organizational activities and practices that may include environmental management by a firm. Stakeholders may include customers, government, 
societies, Non-Governmental organizations, shareholders and employees. Each of the identified stakeholders has different environmental demands on the business firm. Customers may demand that an organization follow certain environmental standards. Employees affect a firm's ability to implement environmental programs successfully. Government on the other hand influences a firm environmental activities by providing regulatory programs that all firms are expected to comply with to avoid any legal action by the government. Societies and NGOs impacts on a firms environmental activities by encouraging unethical firms to be socially responsible by mobilizing public action and pressure against firms activities if they are not environmentally friendly.

\subsection{Sustainable Procurement Policy}

The Chartered Institute of Purchasing \& Supply (2012) points out that the organization should set clear and agreed upon sustainable goals and objectives of procurement embodied in the sustainability policies, strategies, procedures and process. The sustainable objectives should ensure that the objectives are regularly reviewed, the sustainability policy must be endorsed by organization top management team, the organizations sustainable procurement strategy be align to agencies strategic plan, organization regularly checks on and reviews procurement strategy covering risks and supplier engagement.

\subsection{Supply Chain Risk Management}

Risk Management looks at the comprehensive risk management strategy developed by an organization. It ensures organizations effectively and efficiently manage: legal risks, financial risks, ethical risks, security and supply risks, price volatility risks, organizational reputation risks. Risk management, is a formal process that involves identifying potential losses, understanding the likelihood of potential losses, and assigning significance to these losses. (Giunipero \& Eltantawy, 2004) Supply chain management seeks to reduce risks associated with procurement process and enhance competitive performance of the organization by closely integrating internal functions within the firm and effectively linking them with the external operations of suppliers, channel members and final customers. Risks in the supply chain process involves the potential for the occurrence of events associated with inbound supply that may have significant damaging effect on purchasing firms and by extension the environment (Zsidisin et al., 2000). Supply managers must have the ability to understand risk and prepare strategies to mitigate the consequences of risks. Some of the factors that create risk in procurement may include product availability; distance from source, demand fluctuations, changes in technology, financial instability (MacKinnon, 2002). Risk management in procurement is continuous process that involves long term dedication of supply chain members. Ongoing risk assessment process will include: gathering, communicating and evaluation information that aid in developing smart risk management strategies. Risks may be due to disrupted supply, transportation risks. To manage risks effectively, methods that may be used may include: working closely with channel members, mergers and alliances formation, use of e-procurement to integrate supply chains, joint buyer supplier efforts and other measures (Stemper, 2002; Antonette, 2002; Cavinato \& Kauffma, 2000)

\section{Research Methodology}

\subsection{Study Design}

This was a comparative study, aimed to compare sustainable procurement practices used in Athinai Sisal Estate and Lomolo (1962) Ltd. This design was selected to establish whether the sustainable procurement strategies adopted by these firms are no significantly different.

\subsection{The Study Respondents}

The researcher purposively selected Procurement, Production, Marketing and Accounts and finance departments to be involved in the research. It is these departments that are involved in procurement operations and employees from these departments are therefore in a position to give the information sought by the study. Because of the small number of employees in these departments, all employees were involved in the study. The number of respondents per department is as presented in table 3.1 .

Table 3.1. Respondents Distribution per Department.

\begin{tabular}{llll}
\hline Athinai Sisal Estate & & Lomolo(1962)Ltd. & \\
\hline Department & Number & Department & Number \\
\hline Procurement & 6 & Procurement & 9 \\
Production & 20 & Production & 27 \\
Marketing & 9 & Marketing & 10 \\
Accounts and finance & 8 & Accounts and finance & 10 \\
Total & 47 & Total & 62 \\
\hline
\end{tabular}

\subsection{Data Collection Procedure}

In this study, structured questionnaires were developed with separate sections for research item; Supply Chain Efficiency, Supply Chain Risk Management, Stakeholder's Expectation and Awareness and Supply Chain Organizational Policy Commitment. Since data collected was qualitative in nature, a five point likert scale was used to ensure accurate data collection. The questionnaires were self-administered by the researchers to maximize response rate among the respondents.

\subsection{Validity Test}

To test validity of the research instruments, The Cronbach's Alpha was computed for every variable in the study through SPSS. The overall alpha of $0.739,>0.7$ (the threshold value) implies that the instruments were valid and could be used to collect data. The results of the test was as shown in table 3.2 below: 
Table 3.2. Pilot Test Results

\begin{tabular}{ll|l}
\hline Items & Cronbach's Alpha & N of Items \\
\hline Supply Chain Efficiency & 0.804 & 14 \\
$\begin{array}{l}\text { Supply Chain Risk Management } \\
\text { Stakeholder's Expectation and }\end{array}$ & 0.759 & 13 \\
$\begin{array}{l}\text { Awareness } \\
\text { Supply Chain Organizational }\end{array}$ & 0.692 & 10 \\
$\begin{array}{l}\text { Policy Commitment } \\
\text { Alpha }(\alpha)\end{array}$ & 0.701 & 16 \\
\hline
\end{tabular}

\section{Research Findings}

Descriptive analysis was used to establish the level of adoption of the sustainable procurement practices in the Athinai Sisal Estate and Lomolo (1962) Ltd. The findings were as presented in table 4.1 .

Table 4.1. Descriptive Analysis on the Variables.

\begin{tabular}{|c|c|c|c|c|}
\hline Indicator & Firm & & Statistic & $\begin{array}{l}\text { Std. } \\
\text { Error }\end{array}$ \\
\hline \multirow{8}{*}{$\begin{array}{l}\text { Supply Chain } \\
\text { Efficiency }\end{array}$} & \multirow{4}{*}{$\begin{array}{l}\text { Athinai } \\
\text { Sisal Estate }\end{array}$} & Mean & 3.72 & .171 \\
\hline & & Std. Deviation & .922 & \\
\hline & & Minimum & 1 & \\
\hline & & Maximum & 5 & \\
\hline & \multirow{4}{*}{$\begin{array}{l}\text { Lomolo } \\
\text { (1962) Ltd. }\end{array}$} & Mean & 3.71 & .156 \\
\hline & & Std. Deviation & .717 & \\
\hline & & Minimum & 2 & \\
\hline & & Maximum & 5 & \\
\hline \multirow{8}{*}{$\begin{array}{l}\text { Supply Chain Risk } \\
\text { Management } \\
\text { practices }\end{array}$} & \multirow{5}{*}{$\begin{array}{l}\text { Athinai } \\
\text { Sisal Estate }\end{array}$} & Mean & 3.97 & .153 \\
\hline & & Std. Deviation & .823 & \\
\hline & & Minimum & 2 & \\
\hline & & Maximum & 5 & \\
\hline & & Mean & 3.86 & .159 \\
\hline & \multirow{3}{*}{$\begin{array}{l}\text { Lomolo } \\
\text { (1962) Ltd. }\end{array}$} & Std. Deviation & .727 & \\
\hline & & Minimum & 2 & \\
\hline & & Maximum & 5 & \\
\hline \multirow{8}{*}{$\begin{array}{l}\text { Stakeholder's } \\
\text { Expectation and } \\
\text { Awareness }\end{array}$} & \multirow{4}{*}{$\begin{array}{l}\text { Athinai } \\
\text { Sisal Estate }\end{array}$} & Mean & 3.83 & .132 \\
\hline & & Std. Deviation & .711 & \\
\hline & & Minimum & 3 & \\
\hline & & Maximum & 5 & \\
\hline & \multirow{4}{*}{$\begin{array}{l}\text { Lomolo } \\
\text { (1962) Ltd. }\end{array}$} & Mean & 3.81 & .164 \\
\hline & & Std. Deviation & .750 & \\
\hline & & Minimum & 2 & \\
\hline & & Maximum & 5 & \\
\hline \multirow{8}{*}{$\begin{array}{l}\text { Supply Chain } \\
\text { Organizational } \\
\text { Policy } \\
\text { Commitment }\end{array}$} & \multirow{4}{*}{$\begin{array}{l}\text { Athinai } \\
\text { Sisal Estate }\end{array}$} & Mean & 2.99 & .149 \\
\hline & & Std. Deviation & .802 & \\
\hline & & Minimum & 2 & \\
\hline & & Maximum & 5 & \\
\hline & \multirow{4}{*}{$\begin{array}{l}\text { Lomolo } \\
\text { (1962) Ltd. }\end{array}$} & Mean & 2.86 & .173 \\
\hline & & Std. Deviation & .793 & \\
\hline & & Minimum & 2 & \\
\hline & & Maximum & 5 & \\
\hline
\end{tabular}

From table 4.1, the means of 3.72 and $3.71(>3.00)$ reveal that the two companies experience relatively high level of Supply Chain Efficiency. There was no much difference in the level of Supply Chain Efficiency experienced by Athinai Sisal Estate and Lomolo (1962) Ltd. shown by the small difference (0.01) between the means. However, standard deviations; $0.922>$
0.717 reveal that the response on Supply Chain Efficiency in Athinai Sisal Estate was more flexible. This is also shown by the difference in the minimum values ( 1 and 2 ) recorded in the two companies. Since $3.72>3.71$, we can conclude that Athinai Sisal Estate is exposed to relatively higher level of of Supply Chain Efficiency. The means of 3.97 and 3.86 (> 3.00) reveal that the two companies adopt relatively high level of Supply Chain Risk Management practices. The standard deviations of $0.823>0.727$ show that Supply Chain Risk Management practices used by Athinai Sisal Estate are more diverse as Lomolo (1962) Ltd. reveal that the two companies experience relatively similar external end to end risks. However, since $3.97>3.86$, it can be assumed that Athinai Sisal Estate implements relatively higher level of Supply Chain Risk Management practices. Similarly, the means of 3.83 and 3.81(> 3.00) show that the two companies experience relatively high level of Stakeholder's Expectation and Awareness. The standard deviations of $0.711<0.750$ indicates that Athinai Sisal Estate experiences a more diverse Stakeholder's Expectation and Awareness as compared to Lomolo (1962) Ltd. Lastly, the means 2.99 and $2.86(<3.00)$ reveal that the two companies exhibit Supply Chain Organizational Policy Commitment. The higher mean for Athinai Sisal Estate reveal that the company experiences relatively higher Supply Chain Organizational Policy Commitment as compared to Lomolo (1962) Ltd.

From table 4.2 since Levene's test gives $p=0.366$ which is greater than 0.05 on comparison of Supply Chain Efficiency, we use the column for unequal variances; $t=0.041, \mathrm{df}=48, \mathrm{p}$ $=0.97$ under test for equality of means which reveal that there is no statistical difference in the mean response on Supply Chain Efficiency between Athinai Sisal Estate and Lomolo (1962) Ltd. This implies that the two companies are exposed to similar level of Supply Chain Efficiency.

The comparative analysis on Supply Chain Risk Management practices produced Levene's significance value, $\mathrm{p}=0.524$ which is greater than 0.05 . We therefore use tests under unequal variances; $\mathrm{t}=0.482, \mathrm{df}=48$ and $\mathrm{p}=0.632$ under test for equality of means which give evidence that there is no statistically significant difference in the mean response on Supply Chain Risk Management practices between Athinai Sisal Estate and Lomolo (1962) Ltd.

The Levene's $p=0.919$ which is greater than 0.05 for Stakeholder's Expectation and Awareness implies than we assume equal variances. The obtained values; $\mathrm{t}=0.087 \mathrm{df}=$ 48 and $\mathrm{p}=0.931$ reveal that there is no statistically significance difference between Athinai Sisal Estate and Lomolo (1962) Ltd. in as far as Stakeholder's Expectation and Awareness. This implies that the two companies experience similar Stakeholder's Expectation and Awareness

Lastly, comparative analysis on Supply Chain Organizational Policy Commitment produced Levene's significance value, $p=0.834$ which is greater than 0.05 . We therefore adopt tests under unequal variances; $\mathrm{t}=0.632, \mathrm{df}=$ 48 and $\mathrm{p}=0.535$ which implies that there is statistically insignificant difference between level the Supply Chain Organizational Policy Commitment in Athinai Sisal Estate and Lomolo (1962) Ltd. 
Table 4.2. Comparative Analysis on the practices between the Firms.

\begin{tabular}{|c|c|c|c|c|c|c|c|c|c|c|}
\hline & & \multicolumn{2}{|c|}{$\begin{array}{l}\text { Levene's } \\
\text { Test }\end{array}$} & \multicolumn{7}{|c|}{ t-test for Equality of Means } \\
\hline & & \multirow{2}{*}{$\mathbf{F}$} & \multirow{2}{*}{ Sig. } & \multirow{2}{*}{$\mathbf{t}$} & \multirow{2}{*}{ Df } & \multirow{2}{*}{$\begin{array}{l}\text { Sig. } \\
\text { (2-tailed) }\end{array}$} & \multirow{2}{*}{$\begin{array}{l}\text { Mean } \\
\text { Dif. }\end{array}$} & \multirow{2}{*}{$\begin{array}{l}\text { Std. Error } \\
\text { Dif. }\end{array}$} & \multicolumn{2}{|c|}{$95 \%$ C. I of the Difference } \\
\hline & & & & & & & & & Lower & Upper \\
\hline \multirow{2}{*}{ Supply Chain Efficiency } & Equal variances assumed & .834 & .366 & .041 & 48 & .968 & .010 & .241 & -.476 & .495 \\
\hline & Equal variances not assumed & & & .042 & 47.707 & .966 & .010 & .232 & -.457 & .476 \\
\hline \multirow{2}{*}{$\begin{array}{l}\text { Supply Chain Risk } \\
\text { Management practices }\end{array}$} & Equal variances assumed & .412 & .524 & .482 & 48 & .632 & .108 & .225 & -.344 & .560 \\
\hline & Equal variances not assumed & & & .492 & 46.029 & .625 & .108 & .220 & -.335 & .552 \\
\hline \multirow{2}{*}{$\begin{array}{l}\text { Stakeholder's Expectation and } \\
\text { Awareness }\end{array}$} & Equal variances assumed & .010 & .919 & .087 & 48 & .931 & .018 & .208 & -.401 & .437 \\
\hline & Equal variances not assumed & & & .086 & 41.842 & .932 & .018 & .210 & -.406 & .442 \\
\hline \multirow{2}{*}{$\begin{array}{l}\text { Supply Chain Organizational } \\
\text { Policy Commitment }\end{array}$} & Equal variances assumed & .045 & .834 & .625 & 48 & .535 & .143 & .229 & -.317 & .603 \\
\hline & Equal variances not assumed & & & .626 & 43.537 & .535 & .143 & .228 & -.317 & .603 \\
\hline
\end{tabular}

\section{Conclusions and Recommendations}

Athinai Sisal Estate and Lomolo (1962) Ltd. achieve relatively higher level of Supply Chain Efficiency. The two companies operate in the same market environment and as are exposed to similar supplier and product inflow related risks.

Athinai Sisal Estate and Lomolo (1962) Ltd. Adopt relatively high level of relatively similar Supply Chain Risk Management practices. The two companies are in the same line of business and target the same market. They are therefore expensed to similar supply chain environmental factors. This justifies the adoption of similar sustainable practices.

Athinai Sisal Estate and Lomolo (1962) Ltd. companies exhibit relatively high level of similar Stakeholder's Expectation and Awareness. Attention to stakeholders' expectation is inevitable for companies that target diverse markets and that want to excel in business.

Athinai Sisal Estate and Lomolo (1962) Ltd exhibit similar level of Supply Chain Organizational Policy Commitment with Athinai Sisal Estate experiencing relatively higher Supply Chain Organizational Policy Commitment as compared to Lomolo (1962) Ltd. Exposure to external supply chain risks makes an organization vulnerable to disruptions caused by these factors which makes it inevitable for organizations to adopt strategic approach to sustainability.

Based on the findings, the researcher recommends that the processing and manufacturing organizations build sustainability in the internal business operations and take a strategic approach to sustainability. Sustainability in operations should not be left functional areas. It should be management led and should be a cross the organization.

The researcher recommends that further studies should be done on other sustainable business practices such as reverse logistics, just in time and green supply chain management in the sisal processing firms. Studies should also be conducted to establish the role of these practices in operational and other aspects of organizational performance.

\section{References}

[1] Australian Government: Department of Sutainability, Environment, Water Population and Communities (2013). (2013). Sustainable Procurement Guide. Canberra: Commonwealth of Australia.

[2] Bennett, M., James, P., 1998. Environment under the Spotlight-Current Practice and Future Trends in Environment-Related Performance Measurement for Business. Association of Chartered Certified Accountants, London.

[3] Bowen, F. E., Cousins, P. D., Lamming, R. C. and Faruk, A. C. (2001), "The role of supply Management capabilities in green supply", Production and Operations Management, 10 (2), 174-89.

[4] Camerinelli, E. (2009). Measuring the value of supply chain. Farnhan: Gower publishing limited.

[5] Chartered Institute of Purchasing \& Supply (2011). CIPS Sustainable procurement review. Reviewed on 14th January 2015

from:https://www.cips.org/Documents/Products/Sustainable_P rocurement Review \%20new.

[6] Chege, E. N. (2012). Green Supply Chain Management Practice and Supply Chain Performance of Private Hospital in Nairobi, Kenya. Unpublished MBA Thesis.

[7] Chien, M. K. \& Shih, L. H. (2007). An empirical study of the implementation of green supply chain management practices in the electrical and electronic industry and their relation to organizational performances. Int. J. Environ. Science and Technology. 4 (3)383-394.

[8] Commission for Environmental Cooperation (2000). Improving Environmental Performance and Compliance: 10 Elements of Effective Environmental Management Systems. Guidance Document, Commission for Environmental Cooperation.

[9] Cooper, D. R. and Schindler, P. S. (2006). "Business Research Methods", 9th Ed, New York: McGraw-Hill Publications.

[10] Department of Housing and Public Works. (2009). Procurement guidance: Integrating sustainability into the procurement process. The State of Queensland: Department of Housing and Public Works. 
[11] Department of ustainability, Environment, Water, Population and Communities (2013).Sustainable Procurement Guide. Australian Government.

[12] Global Environmental Management Initiative (1998). Measuring Environmental Performance. A Primer and Survey of Metrics in Use. Global Environmental Management Initiative.

[13] Henry, J.-F.-o., \& Journeault, M. (2007). Environmental performance indicators: An empirical study of Canadian manufacturing firms. Journal of Environmental Management 87 (2008) 165-176, 87 (2008), 165-176.

[14] Kombo, D. K., \& Tromp, D. A. (2006). Proposal and Thesis Writing: An Introduction. Nairobi, Nairobi County, Kenya: Paulines Publications Africa.

[15] Kothari, C. R. (2008). Research Methodology-Methods and Techniques. New Delhi: New Age International (P) Limited Publishers.

[16] Marshall, R. S., Brown, D., 2003. Corporate Environmental Reporting: What's in a Metric? Business Strategy and the Environment 12 (2), 87.

[17] Meehan, J., \& Bryde, D. (2010). Sustainable Procurement Practice. Business Strategy and the Environment, 20 (2011), 94-106.

[18] Mosqaard, M. (2009). Green procurement: A Matter of Organizational Change in Elsam Institute for Sam fundsud Vkling of Plan laegning, Ailbord University.

[19] Mugenda, O., Mugenda, A. (2003) Research methods. Quantitative and Qualitative approaches. Nairobi. Africa Centre for technology studies.

[20] Muma, B. O., Nyaoga, B. R., Matwere, B. R. and Nyambega, E. K. (2014). Green Supply Chain Management and Environmental Performance among Tea Processing Firms in Kericho County, Kenya. International Journal of Economics, Finance and Management Science2 (5) 270-276.

[21] Neely, A., Gregory, M., Platts, K., 1995. Performance Measurement System Design: A Literature Review and Research Agenda. International Journal of Operations and Production Management 15 (4), 80-116.

[22] Nijaki, L. K., \& Worrel, G. (2012). Procurement for sustainable local. International Journal of Public Sector, 25 (2), 133-153.
[23] Ninlawan, C., Seksan P., Tossapol K., \& Pilada W. (2010). The Implementation of Green Supply Chain Management Practices in Electronics Industry. Proceedings of the International Multi Conference of Engineers and Computer Scientists, 17-19 March 2010 Hong Kong.

[24] Orodho, A. J and Kombo, D. K. (2002). Research Methods. Nairobi: Kenyatta University Institute of Open Learning.

[25] Preuss, L. (2009). Addressing Sustainable Development Through Public Procurement: The Case of Local Government. Supply Chain Management: An International Journal, 14 (3), 213-223.

[26] Principles and Practices of Public Procurement (2012). Public Procurement Practice, Sustainable Procurement Practice. CIPS and NIGP.

[27] Queen's Printer and Controller (2006). Environmental Key Performance Indicators. Reporting Guidelines for UK Business. Queen's Printer and Controller.

[28] Saleemi, N. A. (1997). Purchasing and Supplies Management Simplified (1st Edition ed.). Nairobi: N. A. Saleemi Publishers.

[29] Sarkis, J., Zhu, Q. \& Lai, K., (2010). An Organizational Theoretic Review of Green Supply Chain Management Literature, Working Paper No.201-2011.

[30] Saunders, M., Lewis, \& M., Thornhill, A. (2012) Research methods for business students (6th Ed). Italy: Pearson education ltd.

[31] Tang, E., \& Chan, R. (1998). Purchasing Behaviors and Perception of Environmentally Harmful Products. Journal of Marketing Intelligence and Planning.16 (6). 356-362.

[32] The Chartered Institute of Purchasing\& Supply. (2012). Sustainable procurement practice. CIPS and NIGP.

[33] UNDP. (2008). Enviromental Procurement: Practice Guide. UNDP Practice series (pp. 18-23). New York: UNDP Procurement Support office.

[34] Walker, H., \& Brammer, s. (2007). Sustainable procurement in the United Kingdom Public Sector. Claverton Down: University of Bath.

[35] Walker, H., \& Philips, W. (2006). Sustainable Procurement: Emerging Issues. International Public Procurement Conference Proceedings. 